\title{
The Duties and Responsibilities of a Medical Teacher
}

\author{
Reddy KR \\ Department of Medical Education, \\ Professor \& Head of Microbiology Department \\ Gandaki Medical College \& Teaching Hospital, Pokhara, Nepal
}

\author{
Keywords \\ Learner, Medical Teacher, \\ Resource person, Role Model. \\ Corresponding author \\ *Dr. K. Rajeshwar Reddy \\ Professor \& Head of Microbiology \\ Department \\ Gandaki Medical College \& Teaching \\ Hospital, \\ Pokhara, Nepal \\ Email: reddysir4861@gmail.com
}

\begin{abstract}
Teachers play vital roles in the lives of the students. Teachers are best known for the role of educating the students. A teacher must be a leader if he/she wants to function effectively in the class room. Teachers set the tone of their class rooms, build a warm environment, mentor and nurture students, and become role models.
\end{abstract}

A teacher is the force that drives the educational system. A teacher is a person who will have to fill many roles. They are people with educational leadership skills and they must continue to grow \& develop as professionals. Anyone seeking to be a teacher should take advantage of any chance they get to grow as a person and as a teacher.

The most important function of a teacher in the current educational context is managerial function consisting of planning, implementing the plan and controlling the educational process. Planning in education involves formulating educational objectives (departmental and institutional) and planning teaching-learning activities. One of the most important factors in the development and implementation of a teaching learning program is the leadership style of the teacher. The controlling process in education is called evaluation. Evaluation, not only monitors the progress and achievements of the students, but also provides important information towards modification and improvement of the teaching-learning process.

This article pertaining to the discipline of Medical Education discusses some important roles, responsibilities and functions of medical teachers.

\section{INTRODUCTION}

The role of the teachers has always been vital in the all round personality development of the students. In fact, a teacher is a role model influencing every facet of the student's growth and developing their innate potentials, in addition to being a motivator, guide and friend ${ }^{1}$.

Besides, the teacher of today is also responsible to enable and empower the learner to emerge as a competent youth, ready to take on the challenges of the rapidly changing world.

Hence, it is imperative that the teacher continuously upgrades his/her knowledge and methodology in order to enhance the quality of teaching. If the quality of teaching is good and the commitment of the teachers is high, the standard of the institution is bound to rise ${ }^{1}$. 
THE RESPONSIBILITIES AND FUNCTIONS OF A MEDICAL TEACHER

To make the education process meaningful, teachers should give attention to the following guidelines regarding their duties and responsibilities.

- Be punctual and be available in the departments during official working hours.

- Follow the policies, standards, rules, regulations and procedures of the Institution.

- $\quad$ Conduct the classes at the scheduled times.

- $\quad$ Reach the class room on time for teaching.

- Plan and prepare well each and every aspect of the topic before the delivery of the lecture.

- Motivate the students before the actual delivery of the lecture.

- Link the topic with the previous knowledge of the students.

- Develop and use the relevant teaching aids.

- Use a combination of different methods and techniques of teaching.

- Interact with the students to induce curiosity, motivate, and provoke thinking, imagination and application of the concept taught.

- Implement the designated curriculum completely and in due time.

- Give activity/application-based work/assignment beyond the book, with guidance to use various resources and keep a record of the work given.

- Engage students in creative thinking and integrated or interdisciplinary learning experiences.

- Maintain cleanliness, discipline, and a safe, orderly environment conducive to learning.

- Mark the attendance of the students in the class register.

- Create learning environment for the students by giving examples of noble work of great personalities to inspire the students.

- $\quad$ Make best use of the laboratory and use models, lab equipment, apparatus to conduct experiments on a regular basis.

- Make a schedule for the practical classes and ensure that the entries in the records and files are not copied.

- Encourage students to prepare and participate in medical/science exhibitions and help them in preparing working models.

- Encourage students to develop reading habits by consulting various text books, journals, magazines etc.

- Help check truancy and long absenteeism among students.

- Collect and compile information related to medical profession and medical education from sources like news papers, magazines etc. and display it through charts, posters, and bulletin boards.

- Hold seminars on various topics relevant to medical profession.

- Must evaluate the students from time to time.

- Display clearly the time table/ teaching schedule of the class.

- Maintain the teacher's diary (log book) daily

- Maintain stock resister of equipments and instruments, chemicals, glass ware and furniture of the concerned departments.

- Participating In-service education and training courses as well as in continuing professional development (Continuing medical education) opportunities.

Therefore, the role of a teacher's overall responsibility and functions, in the educational process has increased tremendously.

\section{Resource person}

A teacher must be a resource specialist and must have expert knowledge of the subject area. Many people including students and coworkers will come to the teacher seeking information. Even if the person is only seeking a source of information, the teacher is the one who must know how to find what the student is looking for ${ }^{2}$.

A leader in a medical college is a teacher who takes on extra tasks. Teachers who are active in their work will often have more jobs than just the one they were hired to perform.

\section{Curriculum specialist}

The most common role a teacher plays in the class room is to teach knowledge to students. Teachers are given 
a curriculum they must follow that meet concerned University guidelines. This curriculum is followed by the teacher so that throughout the year, all pertinent knowledge is dispensed to the students.

Understanding content standards, how various components of the curriculum link together, and how to use the curriculum in planning instruction and assessment is essential to ensuring consistent curriculum implementation throughout a medical college.

\section{Instruction specialist}

A teacher must be an instructional specialist. An instructional specialist helps colleagues implement effective teaching strategies. This help might include ideas for differentiating instruction or planning lessons in partnership with fellow teachers ${ }^{1}$.

\section{Role model}

Teachers typically do not think of themselves as role models, however, inadvertently, they are. Students spend a great deal of time with their teachers and therefore, the teacher becomes a role model to them. Students look up to the teachers and may pattern their own behavior and work ethic to match the instructor. Teachers are there not only to teach the students, but also love and care for them. Teachers are typically highly respected by people in the community and therefore become a role model to students and parents.

Students learn from what they see rather than from what they are taught. This is especially true for the development of attitudes. It is essential that teachers should help students acquire desirable skills and attitudes by providing a role model ${ }^{4}$.

\section{Mentor}

Mentoring is a natural role taken on by Teachers, whether intentional or not. Mentoring is a way a teacher encourages students to strive to be the best they can. This also includes encouraging students to enjoy learning. Part of mentoring consists of listening to students. By taking time to listen to what students say, teachers impart to students a sense of ownership in the class room. This helps build their confidence and helps them want to be successful. An older teacher can even be a mentor to a younger teacher who is just starting out in the profession ${ }^{5}$.

\section{Learner}

A learner is a person who is always growing in life and will never claim that they know it all. A teacher is challenged everyday with a new task that will help them grow into a better person. Anyone who has been involved in a profession long enough knows that there is always something new to learn.

In the present era of information explosion, a teacher has to keep up with the scientific literature in his/her discipline and choose relevant information for the teaching and learning of MBBS students. Furthermore, the teacher should also try to be aware of the recent developments in medical education so that he/she could facilitate the learning by students effectively and efficiently ${ }^{6}$.

\section{Learning facilitator}

Facilitating professional learning opportunities among staff members is another role for teacher leaders. When teachers learn with and from one another (professional learning), it becomes more relevant, and they can focus on what most directly improves student learning ${ }^{3}$.

\section{Communicator}

Communication is not only transfer of information from a teacher to the student, but also a two-way process of sharing thoughts and feelings. Communication could be verbal or non-verbal and includes the use of appropriate audiovisual aids to facilitate the process. Important principles of verbal communication include the use of simple language, familiar words and emphasis by repetition. Non-verbal communication is as important as verbal communication. It includes the maintenance of a uniform eye contact, and the use of facial expressions and body gestures (body language) to convey desirable attitude ${ }^{3,7}$.

\section{Research worker}

Medical teachers should have a scientific attitude and should be willing to generate new ideas and try them out to facilitate teaching-learning process in their setting ${ }^{1}$.

\section{CONCLUSIONS}

Teachers exhibit leadership in multiple, sometimes overlapping ways. Some leadership roles are formal with designated responsibilities. Other more informal roles emerge as teachers interact with their peers. The variety of roles ensures that teachers can find ways to lead that fir their talents and interests. Regardless of the roles they assume, teacher leaders shape the culture of their medical colleges, improve student learning and influence practice among their peers. 


\section{REFERENCES}

1. Brownell AK, Cote L. Senior residents' views on the meaning of professionalism and how they learn about it. Acad Med. 2001; 76(7): 734-7.

2. Prideaux D, Alexander H, Bower A, Dacre J, Haist $\mathrm{S}$, Jolly $\mathrm{B}$, et al. Clinical teaching: Maintaining an educational role for doctors in the new health care environment. Med Educ. 2000; 34(10): 820-6.

3. Curry SE, Cortland CI, Graham MJ. Role-modelling in the operating room: Medical student observations of exemplary behaviour. Med Educ. 2011; 45(9): 946-57.
4. Butani L, Paterniti DA, Tancredi DJ, Li ST. Attributes of residents as teachers and role models-a mixed methods study of stakeholders. Med Teach. 2013; 35(4): e1052-9.

5. Sutkin G, Wagner E, Harris I, Schiffer R. What makes a good clinical teacher in medicine? A review of the literature. Acad Med. 2008; 83(5): 452-66.

6. Ramani S, Leinster S. AMEE Guide no. 34: Teaching in the clinical environment. Med Teach. 2008; 30(4): 347-64.

7. Spencer J. Learning and teaching in the clinical environment. BMJ. 2003; 326(7389): 591-4. 